\author{
Michał Jakubowicz \\ SWPS University of Social Sciences and Humanities \\ jakubowicz88@gmail.com
}

\title{
MANIFESTATIONS OF PUBLIC ART
}

\begin{abstract}
Within the article "Manifestations of public art" and through photographic projects (subPark 2014-..., Travel Documents, 2015-2016), I am asking the question whether modern art needs and strives for nature in proxemic and historical dimension as an area of "salvaged green", evoking ways of viewing specific to pre-war architects of cities incorporated into Polish borders after 1945. Grabiszyński Park, former German cemetery, demolished in the 1960s, eventually transformed into a green area. Structures of trees are subjected to creative analysis comprised in categories of anonymous manifestations of public art. Community of outliers born within the area of pre-war city and its vicinity as well as expelled Germans and emigrants photographed in several parks of Poland and Germany were invited to participate in the project. The position regarding visual form being the result of social relations and the phenomenon of autoreference has been presented.
\end{abstract}

Keywords: Anthropothanatology, German cemeteries, Breslauers, site specific, relations, participation.

The subPark project is characterized by many aspects, includes various narratives and does not yet have the so-called ending ${ }^{1}$ because it still consists in looking at a specific space in Wroclaw - the space of Grabiszyński park, which before the war was a green part of the German cemetery - the former Kommunal Fried hof in Gräbschen. ${ }^{2}$ The contemporary concept of the Grabiszyński Park is a consequence of the decision of communist authorities to demolish German cemeteries within the areas annexed to Poland in 1945. The new for-

1 G. Deleuze, F. Guattari, Tysiac Plateau. ed. J. Bednarek. Warszawa 2015, pp. 3-30.

2 M. Burak, H. Okólska, Cmentarze dawnego Wrocławia. Wrocław 2007, pp. 237-241. 
mula of green space established in 1993 interweaves with those 'traces', thus provoking a unique experience, and constitutes a combination of a disturbing historical background with everyday objects - playgrounds, running tracks, or monuments. I wonder whether today, after the German-Polish reconciliation and acceptance of the German-Polish border by the Federal Republic of Germany, the presence of both countries in the European Union, but also after the global crisis and in the context of intensifying nationalisms, the history of the park can be still disturbing, and what types of discussions and attitudes it will initiate. After all, there are many more such 'places of oblivion' in the western and northern areas of Poland. Do we need them to create the presence?

In 2014, I initiated a photographic documentation of German traces within the Grabiszyński Park, indicating the temporary nature of the space. I was interested in the structure of "salvaged green", ${ }^{3}$ distinguishing itself from the surroundings in the form of the rhythmic arrangement of surviving trees, on the one hand the former cemetery quarters, spaces of contemplation and places of rest, and on the other, autonomous Modernist works of art consisting of concretization and embodiment of visual forms that belong to the generational mechanisms. ${ }^{4}$ As a result of such an approach to the public space in Wroclaw I became an observer of social and natural systems through their visual manifestations. However, the following question arose: whose manifestations?

Using photography and exhibitions, I transferred the park objects - manifestations of anonymous public art, from the local park to the artistic and cultural context of the gallery. The exhibitions were implemented in several of the many cities annexed to Poland after the Second World War, i.e. Piła, Słubice, Szczecin, Wrocław, as well as villages, in this case: Sokołowsko. The issue of creating new meanings or posing as a commentator or critic of phenomena is an open part of the project, therefore it is left to the public. This is where I see the subversive aspect of the work. I suppose that images can provoke difficult questions associated with the history and politics, as well as in depth with the privacy and identity of people living in these areas now and in the past, creating from these symbolic elements their worlds of experiences, their life stories and histories. In this sense, it is not a convenient proposition that provides ready formulas. It evokes what is invisible and suppressed in the public space, while it also shows that the space marked by the trauma of abandonment and erasure can still be subject to artistic transformations. The history of the cemetery is not objective, because objects that created it no longer exist, while the visual arts are characterized by generative methods of modeling artificial worlds. In

3 K. Ruchniewicz, Cmentarz można zburzyć - pamięci nie sposób. 2013 \#bloghistoria.

4 G. Jäger, Rolf H. Krauss, Beate Reese, Concrete Photography / Konkrete Fotografie. Bielefeld 2005. 
this case, objects used as creative instruments include: camera, video camera, charcoal (for copying inscriptions), which are associated with images, but also the park space itself is treated as a large cultural camera, used to reveal images and concretize an undefined social form. Current for me is the tradition of painting and readymades co-creating the contemporary public space in the area of not only great art systems, politics and economy, but also local social communication, civic attitudes, expression of identity, images and collectivity. ${ }^{5}$ Manifestations of public art observed in the Grabiszyński Park in Wrocław are not pieces of work designed by artists to express a specific idea. It is a fragment of the urban landscape in an institutionally changed context, which starts to live a new life, referring in its form to past experiences, functions and purposes. In order to perceive formal differences one needs to experience them anew. The subject of the project in which the main theme is a park created within the area of a cemetery demolished about half a century ago justifies the use of tree images in their symbolic arrangement, evoking the sense of emptiness, however, where are the people?

At certain stage, I started to wonder how to involve people in the project in a different way than just as a gallery audience. The latter has been narrowed down to the residents of cities facing the problem, due to the fact of living in the so-called "post-German" areas (in this case, I am not focusing on Czech, Jewish, Austrian, or Polish influences found in Silesia ${ }^{6}$ as they are of marginal significance with regard to the proxemics and park antropotanathology in which I am interested here). The project was exhibited in the centers focused on German-Polish cooperation (e.g. Municipal Cultural Centre in Słubice) or in the places that take into account pre-war traditions in their programs (Galeria MS in Piła, Klub Storrady in Szczecin, Galeria Wykwit in Wrocław). Formally, my photographs include many simplifications - in fact, many were created in the landscape style (stylistic simplification). I also stayed away from digital technology, instead using "dead media" of analogue photography, while in some series I gave up using a camera in favor of contact photography, which emphasizes relationship of the image with the presented object (in this case: in effect of the tree surface and the park atmosphere), and in one of the cycles the photosensitive material was replaced with a matrix of gray paper and charcoal for stone rubbing. However, the above-mentioned activities are mainly associated with the gallery audience. There was no audience interested in the issue that I could include in the implementation of this project.

5 Cf. C. Bishop, Sztuczne piekta. Sztuka partycypacyjna i polityka widowni. Warszawa 2005, p. 84.

6 N. Davies, R. Moorhouse, Mikrokosmos. Kraków 2002, pp. 83-357. 
In 2015, I established contact with the German Cultural and Social Association in order to invite people born in the area of modern Wrocław before 1945, the so-called Breslauers, to have their photographic portrait taken. At first I intended to photograph Breslauers in the Grabiszyński Park, showing residents who have been living in Wrocław since the pre-war times in the area of the former German cemetery. However, the attempts to contact Breslauers failed to bring any response and only the help of one of the participants of the lecture about subPark project ${ }^{7}$ - in fact, a representative of the audience, dr Dorota Płuchowska, make it possible to take a series of portraits, albeit in different conditions. The project evolved and became independent of the subPark concept, subject to the decisions of the participants. The first photographs were taken not in the Grabiszyński park, but in a park near the Institut für Migrations und Aussiedlerfragen in Oerlinghausen, which supported the project organizationally. The intention was to portray people born in the area of Wrocław and Silesia before 1945 and currently living in Germany. The structure of six photographs was determined, presenting exiled people living in Germany and six inliers living in Poland, photographed against the background of greenery, in a manner that would not reveal the place and nationality of the portrayed person. The photographs taken in Germany have become the proof of establishing contacts in Poland with the German Cultural and Social Association in Wrocław and Wałbrzych, as well as the Association of Enthusiasts of the Kącka Land in Katy Wrocławskie. The number of institutions involved in the project on the Polish side is best illustration of the efforts but also errors in the relations. The title proposed in the initial phase - "Wypędzeni z fotografii" (The exiled from photography), corresponding to the German narratives concerning expulsions, turned out to be imprecise already during the photo shoots in Oerlinghausen. People who consider themselves as exiled or emigrants applied for the project. In Poland, the situation was different and it may have influenced some difficulties in attracting participants. Mrs Doris Stempowska, the president of the German Cultural and Social Association in Wałbrzych, who was participating in the project also as a photographed person, simply stated: "none of us here have been exiled". In fact, after the war, a part of the German population was needed for work not only at the lowest levels of positions, but also as specialists who knew the technology abandoned by the Germans. One of the photographed persons, Weronika Rink who was born in Berlin, came to the Polish village near Opole in 1964 and returned to Germany in 1987. In 1964, her parents did not see the difference between living in the GDR and the Polish People's Republic, because both countries were at that time under the

7 Lecture subPark. Komunikacje w rozmowie, lead by: M. Grech, Klubokawiarnia Literatka, Wrocław 24.03.2015. 
same Soviet domination and they chose the context of the territory that was closer to them and not the nation. The diverse stories of the participants lent it the euphemistic title of Dokumenty podróży ("Travel documents"), inspired by the documents of Mattern Gretel - and her family - issued for their departure from Poland with no option to return. In the materials made available by the German woman, I got interested in the change of name made by the Polish People's Republic authorities from the "identity document" to the "travel document”.

In regard to the participation of photograph models in the designing and redistribution deeply inscribed in the structure of this piece of work, I methodologically perceive the activities described here in the relativity line ${ }^{8}$ where the end result comes from the observed or existing social systems. I see the role of the artist as the person managing the systems and taking care of their auto-reference identified with the emancipation of the piece of work. I think that not only the artist decides how much power over the project he/she can give to its participants (obviously the personality and mediation competence are important issues in this case), but also the subject itself verifies the interest of the audience. During the work with people, where different perspectives and points of view are taken into account, the agreements on the subject, roles and meanings become extremely important. Inevitably, these issues reduce the intuitive approach, which is an important element of the pieces of work. For me, the participation means taking into account social relations and people as part of a piece of work, the form of which results from these relations, while the participation of artistic project in a social system is perceived by me on analogous principles. One cannot ignore the auto-reference of art within social systems.

The last portrait photograph creating a set of twelve photographs of $D o$ kumenty podróży was taken in the Grabiszyński Park in April 2016. It presents Helga Wendlandt, who was born in Breslau in 1936. The juxtaposition of the two projects - Dokumenty podróży and subPark for the first time took place during the exhibition in Sokołowsko (Między drzewami [Between the Trees], 2018) and it was also presented in the photography book "sub" (Libron, 2018).

\section{BIBLIOGRAPHY}

Bishop C. (2005) Sztuczne piekła. Sztuka partycypacyjna i polityka widowni. Warszawa: Fundacja Bęc Zmiana.

8 N. Bourriaud, Estetyka relacyjna. Kraków 2012, p. 43. 
Bourriaud N. (2012) Estetyka relacyjna. Kraków: MOCAK.

Burak M., Okólska H. (2007) Cmentarze dawnego Wrocławia. Wrocław: Muzeum Architektury we Wrocławiu.

Davies N., Moorhouse R. (2002) Mikrokosmos, Kraków: Znak.

Deleuze G, Guattari F. (2015) Tysiac Plateau. ed. J. Bednarek, Warszawa: Fundacja Bęc Zmiana.

Jakubowicz M. (2016) subPark. Kraków: Libron.

Jakubowicz M. (2018) sub. Kraków: Libron.

Jäger G., Krauss R.H., Reese B. (2005) Concrete Photography / Konkrete Fotografie. Bielefeld: Kerber Verlag.

Lecture subPark. Komunikacje w rozmowie, lead by: M. Grech, Klubokawiarnia Literatka, Wrocław 24.03.2015.

Ruchniewicz K. (2013) Cmentarz można zburzyć - pamięci nie sposób, \#bloghistoria.

\section{MANIFESTACJE SZTUKI PUBLICZNEJ (streszczenie)}

W artykule Manifestacje sztuki publicznej nawiązuję do moich fotograficznych projektów (subPark 2014 -... i Dokumenty podróży, 2015-2016). Stawiam pytanie, czy we współczesnej Polsce chcemy patrzeć na przyrodę w wymiarach proksemicznym i historycznym - czy interesuje nas „zieleń ocalała” pozwalająca poznać sposoby widzenia charakterystyczne dla przedwojennych architektów, którzy tworzyli miasta przyłączone do Polski po 1945 r.? Uwaga moja skoncentrowana jest na specyficznej przestrzeni parku Grabiszyńskiego, niegdyś niemieckiego cmentarza, zniszczonego w latach 60. ubiegłego wieku i ostatecznie przekształconego w miejski teren zielony. Analizie twórczej podane zostały wciąż istniejące struktury drzew ujmowane jako anonimowe manifestacje sztuki publicznej. Do udziału w projekcie zaproszona została też społeczność ostańców, mężczyzn i kobiet urodzonych na terenie przedwojennego Wrocławia i okolic, a także Niemców wypędzonych i emigrantów. Rozmawiałem z nimi o parku Grabiszyńskim i fotografowałem ich w kilku parkach Polski i Niemiec. W artykule przedstawione jest też stanowisko nt. formy wizualnej będącej wynikiem relacji społecznych oraz zagadnienie autoreferencji.

Słowa kluczowe: niemieckie cmentarze, Breslauerzy, antropotanatologia, site specific, relacje, partcypacja. 


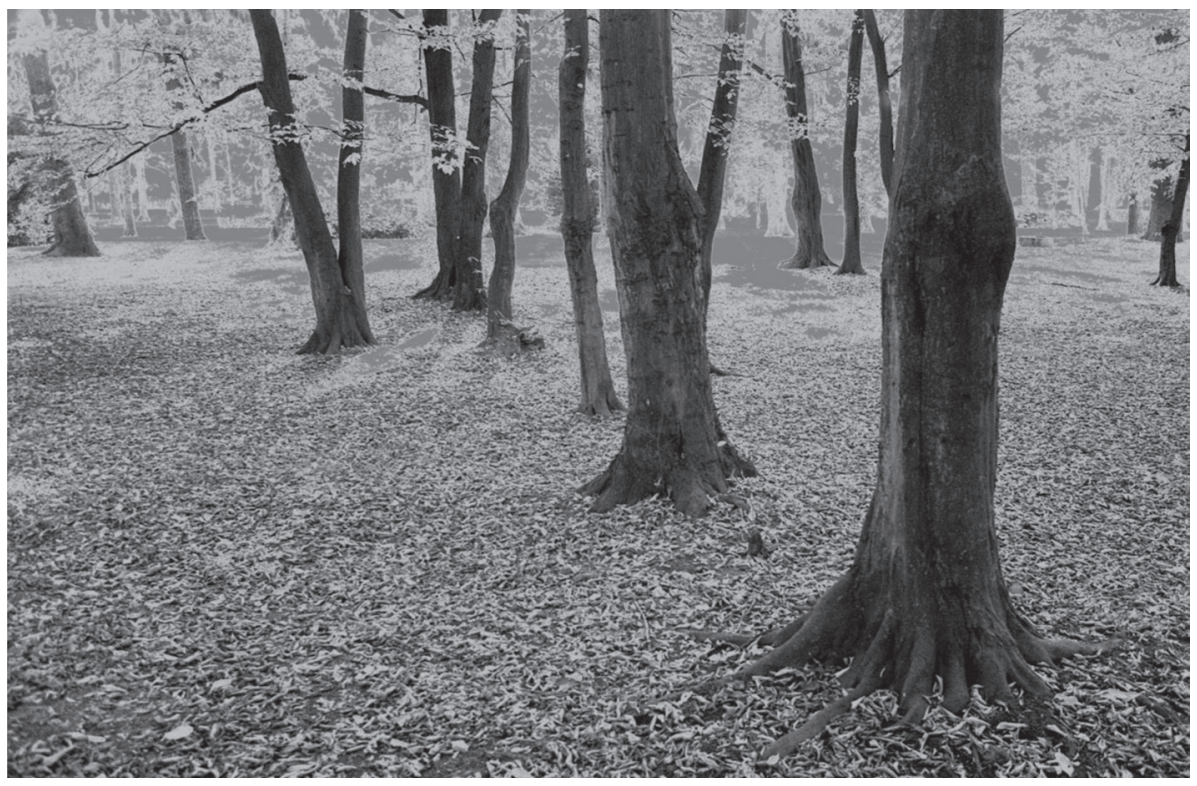

Phot. 01 - M. Jakubowicz, (2014) Notacje. (Notations. Structures). photo, format $20 \times 30 \mathrm{~cm}$

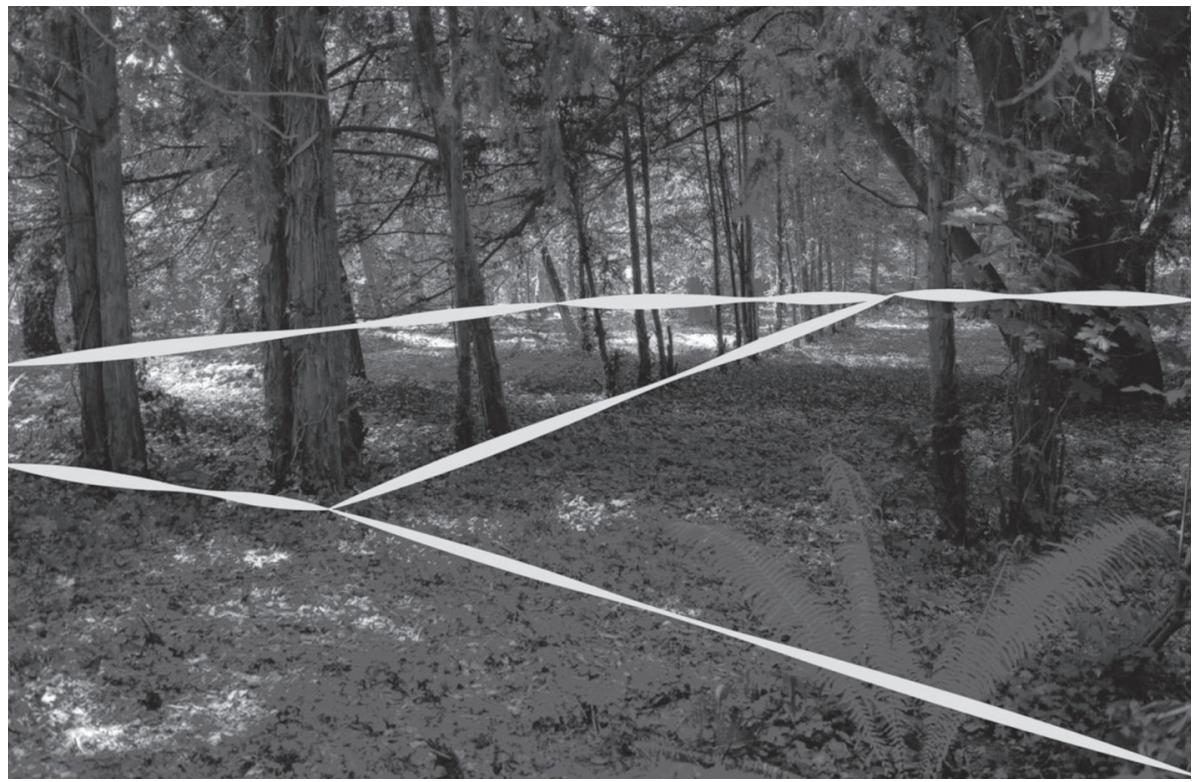

Phot. 02 - M. Jakubowicz, (2016) Miejsca (Places), photo, format 13x18 cm 


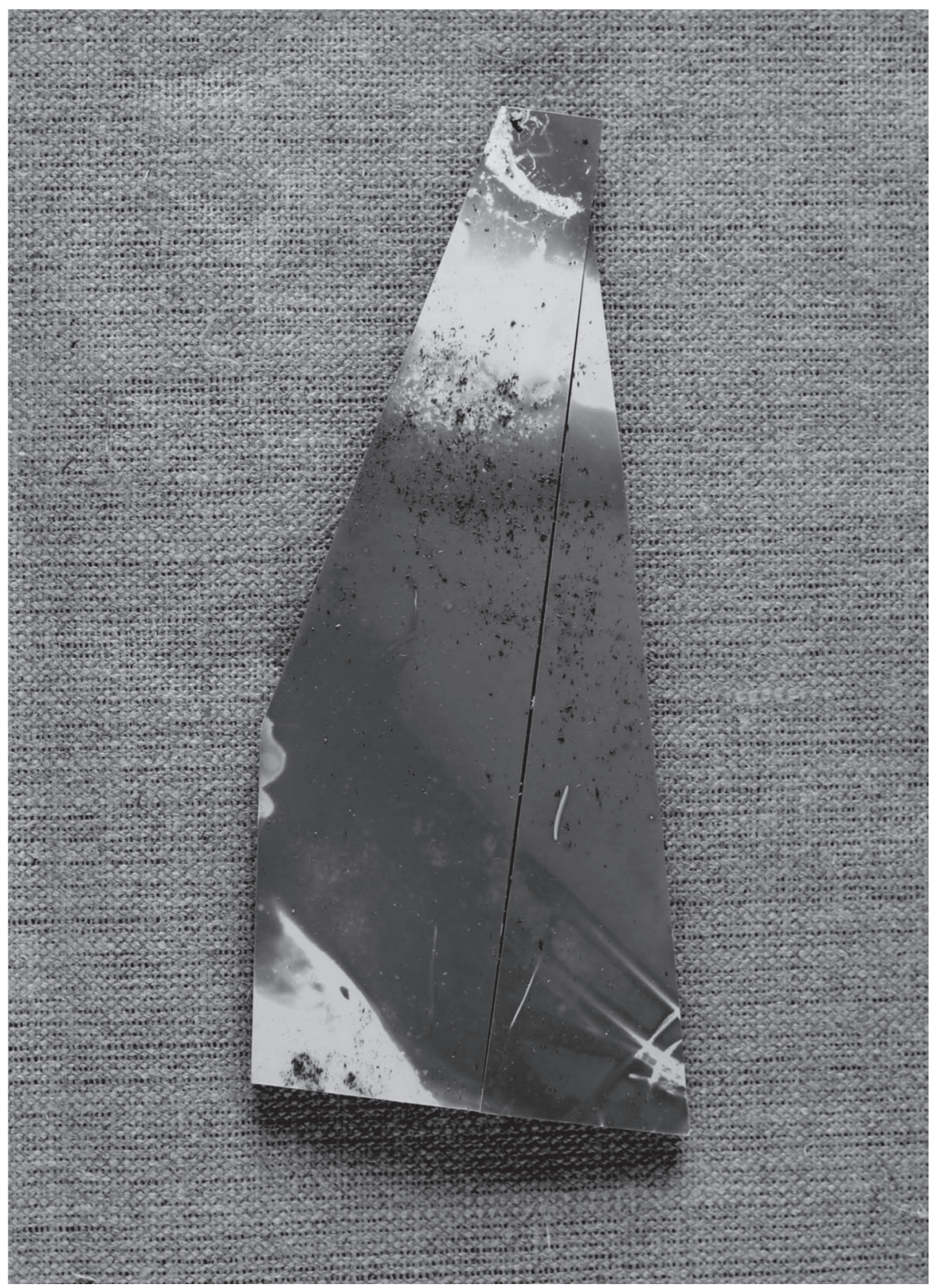

Phot. 03 - M. Jakubowicz, (2016) Czujnik światła (Light sensor), Mixed technique: photogram, photo, format $20 \times 30 \mathrm{~cm}$ 


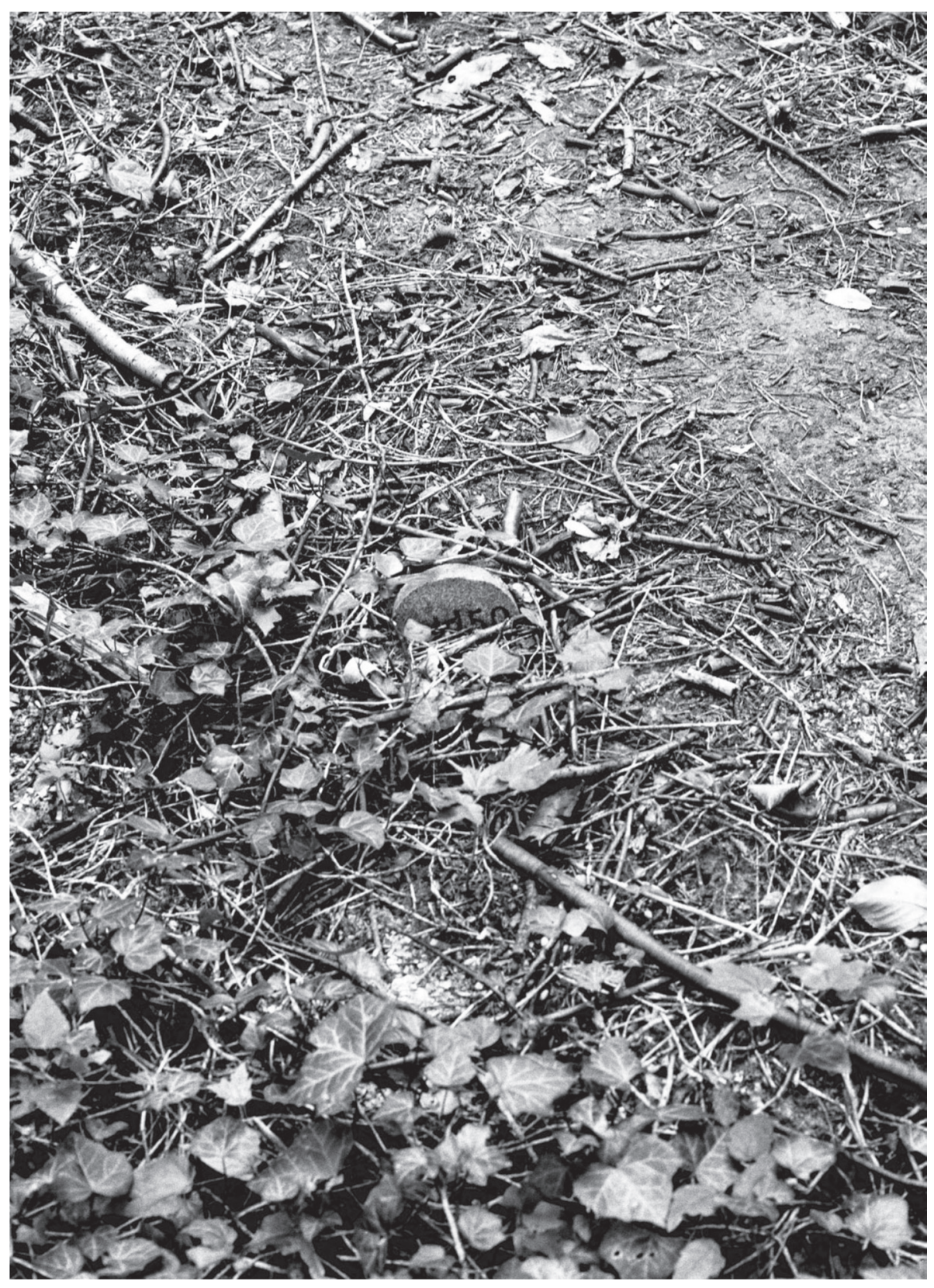

Phot. 04 - M. Jakubowicz, (2015) Nieistniejący cmentarz 2 (Non-Existent Cemetery 2), photo, format $20 \times 30 \mathrm{~cm}$ 

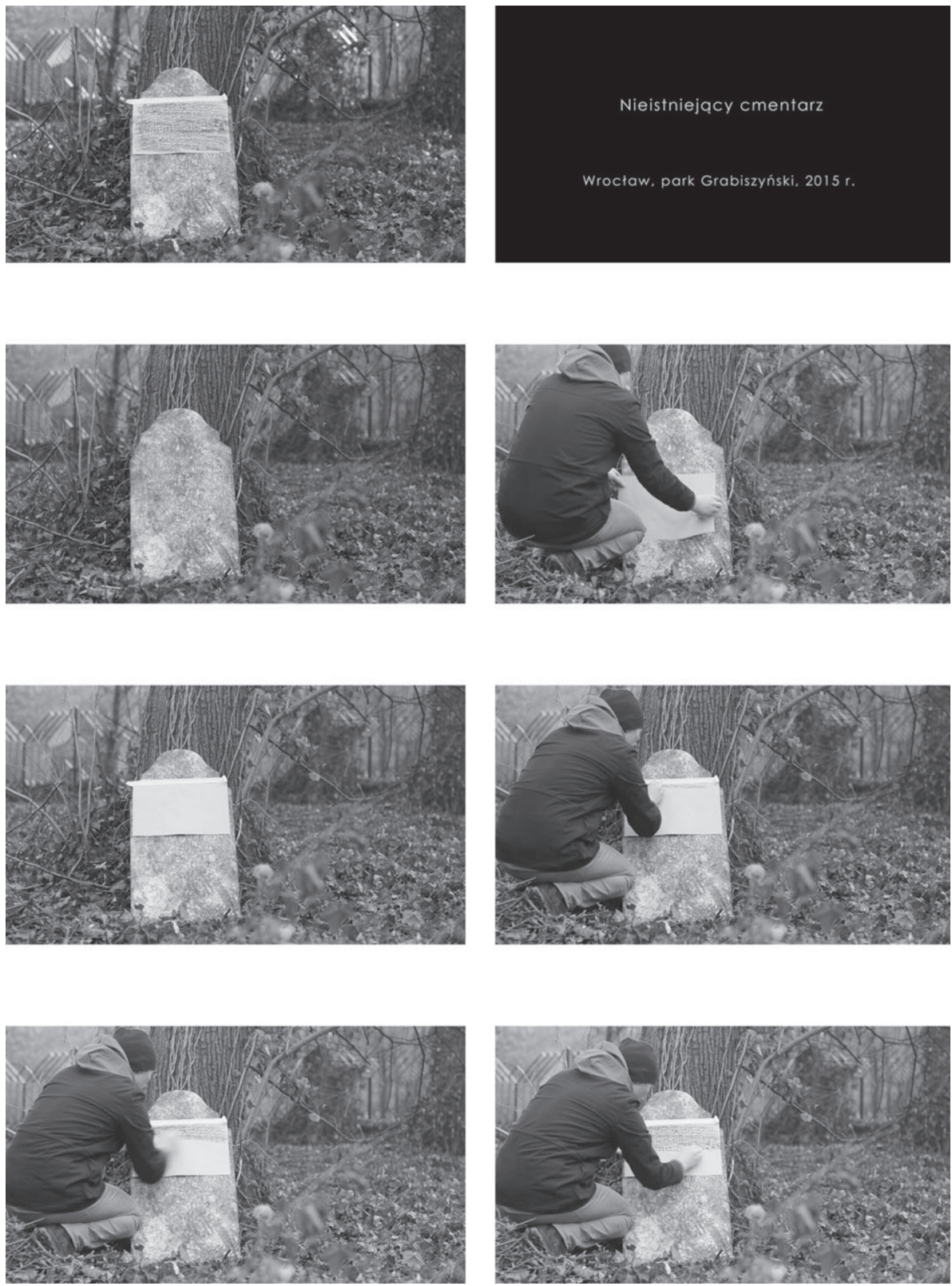

Phot. 05 - M. Jakubowicz, (2015) Nieistniejący cmentarz (Non-Existent Cemetery), movie screens. 


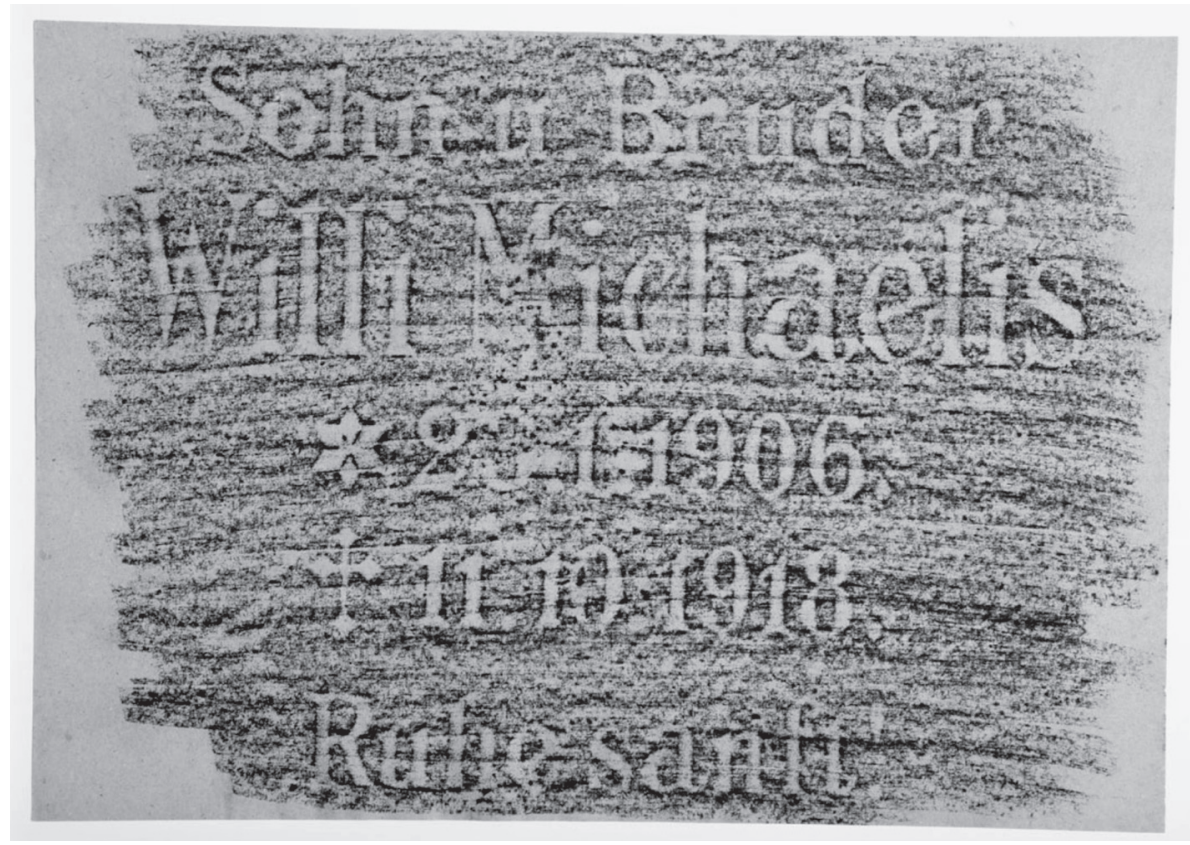

Phot. 06 - M. Jakubowicz, (2015) Nieistniejący cmentarz (Non-Existent Cemetery), frottage, format $30 \times 40 \mathrm{~cm}$ 


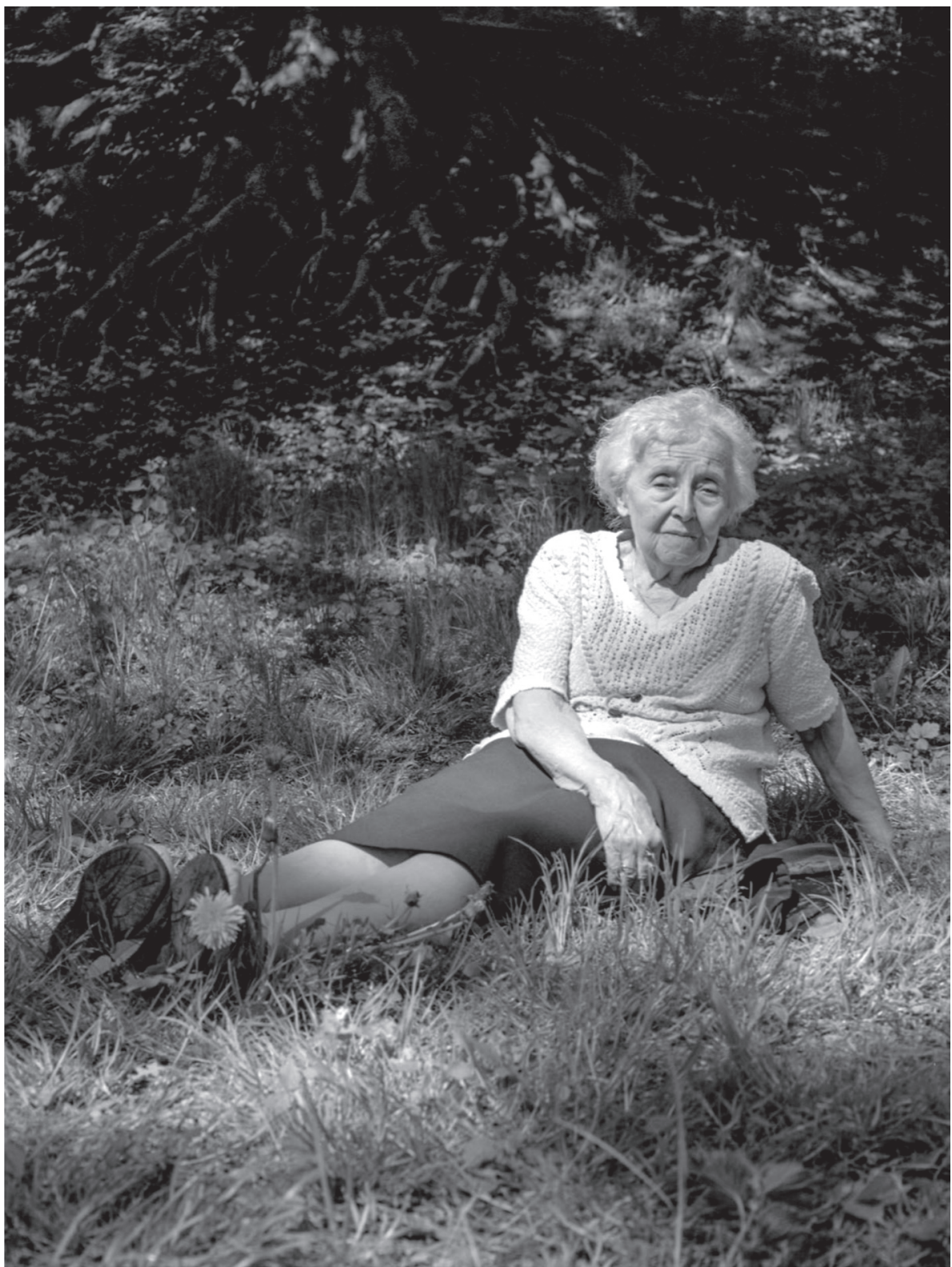

Phot. 07 - M. Jakubowicz, (2015-2016) Travel Documents. Doris Stempowska, color photo, format $30 \times 40 \mathrm{~cm}$ 


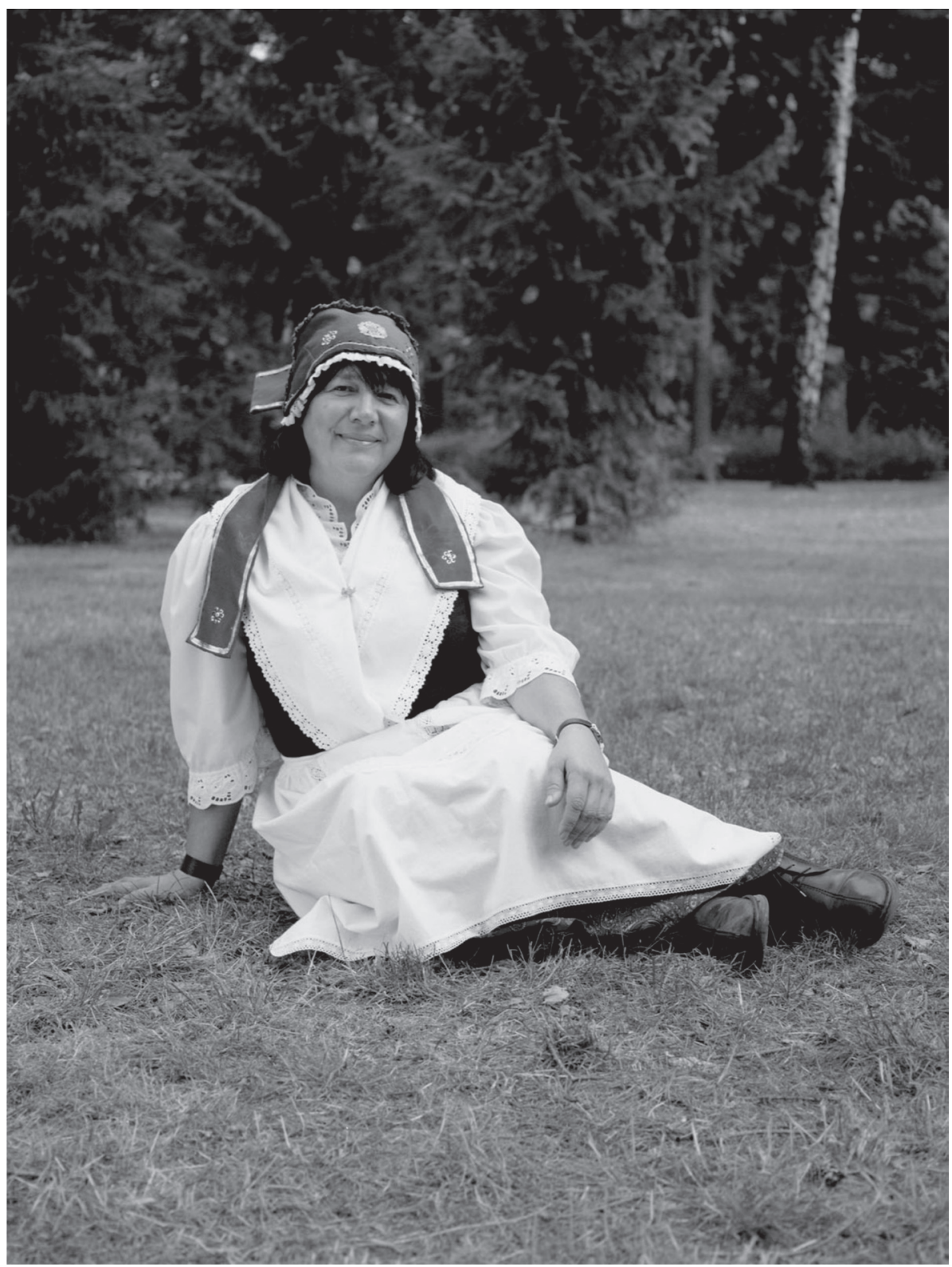

Phot. 08 - M. Jakubowicz, (2015-2016) Travel Documents. Anna Przytulecka, color photo, format $30 \times 40 \mathrm{~cm}$ 


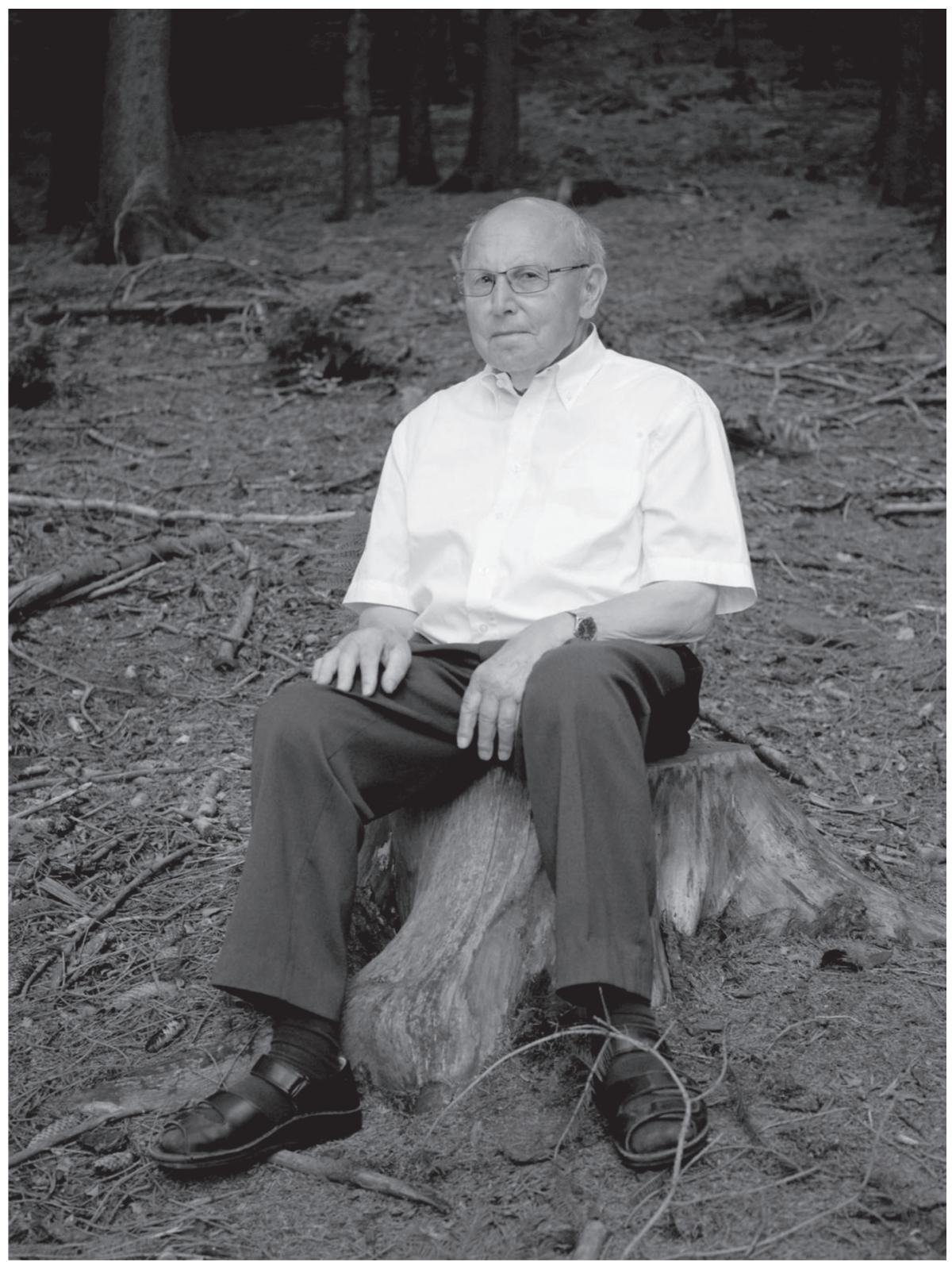

Phot. 09 - M. Jakubowicz, (2015-2016) Travel Documents. Josef Engel, color photo, format $30 \times 40 \mathrm{~cm}$ 


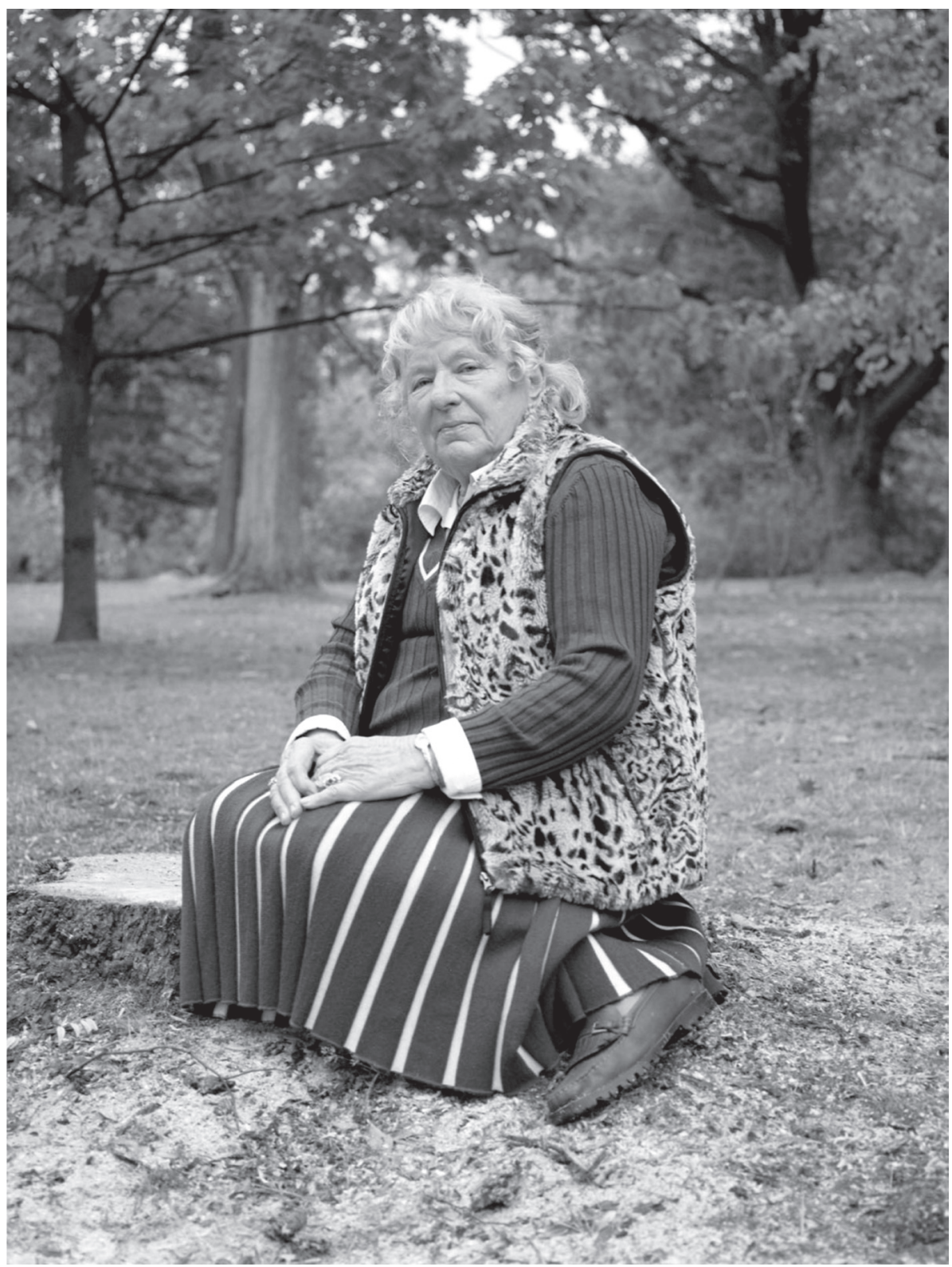

Phot. 10 - M. Jakubowicz, (2015-2016) Travel Documents. Helga Wendlandt, color photo, format $30 \times 40 \mathrm{~cm}$ 